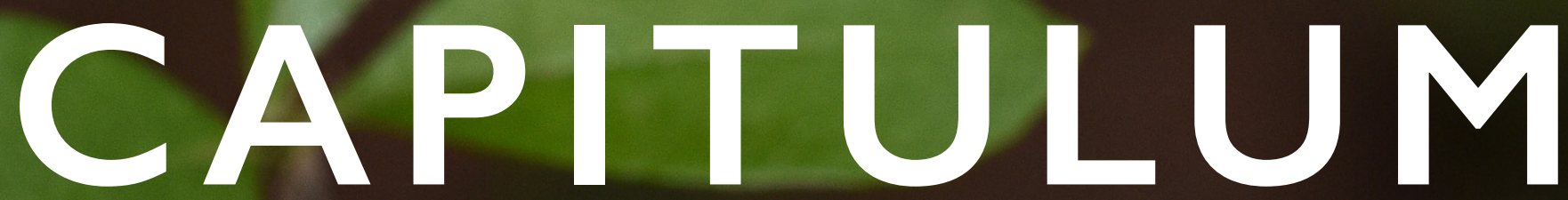

THE INTERNATIONAL COMPOSITAE ALLIANCE NEWSLETTER

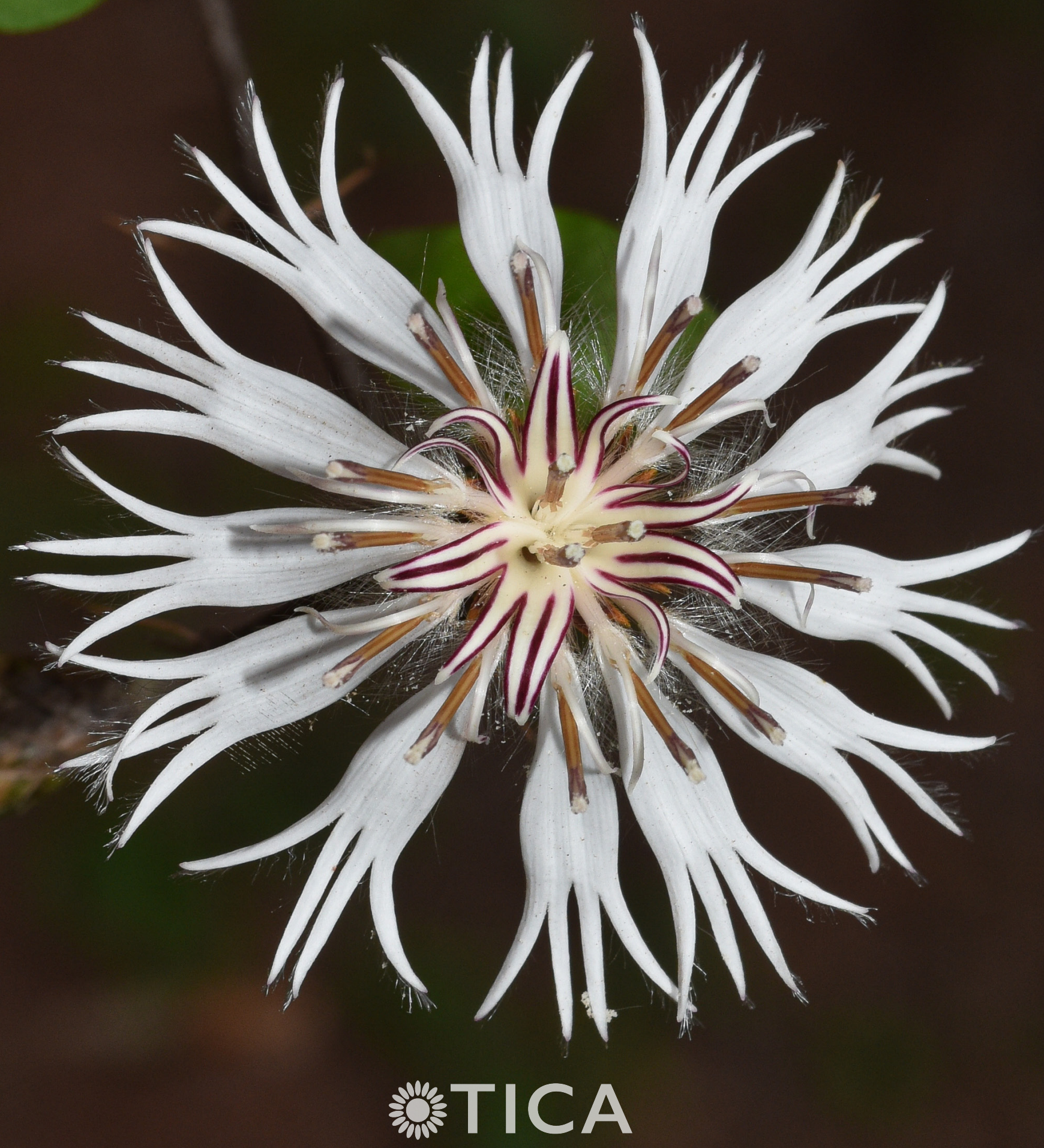




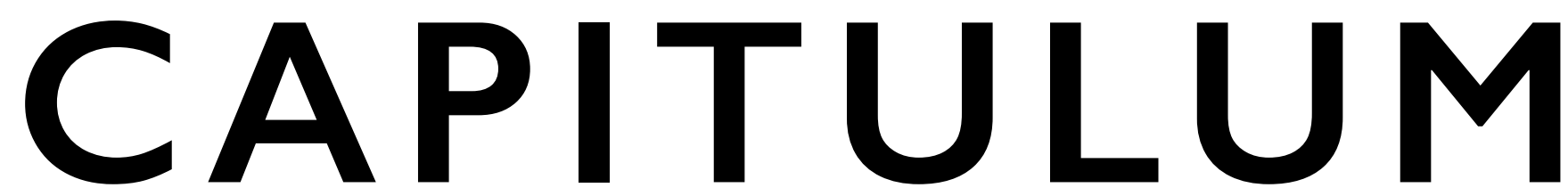

THE INTERNATIONAL COMPOSITAE ALLIANCE NEWSLETTER

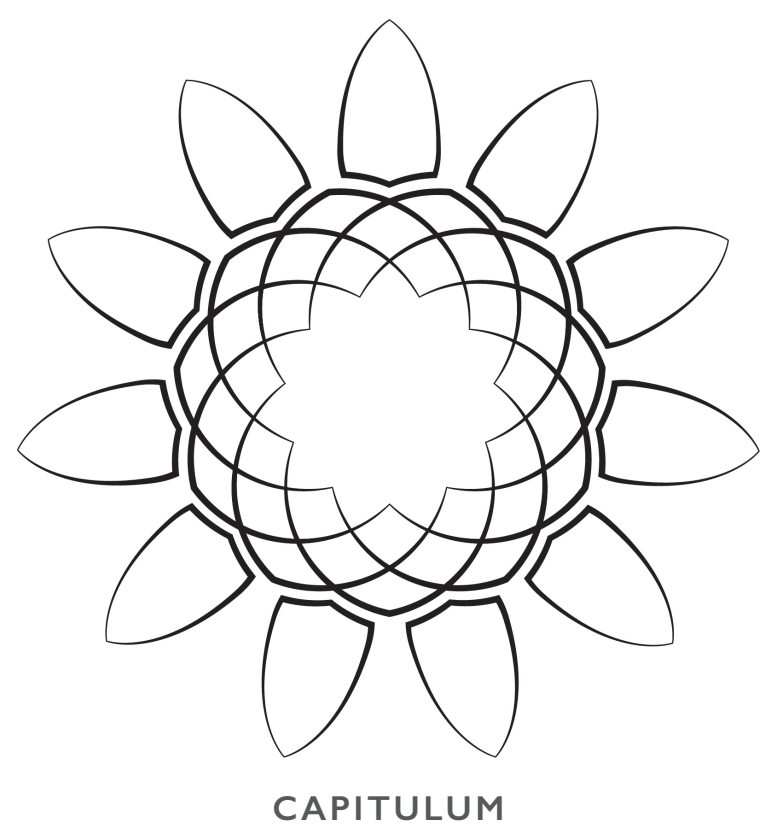

For the community \& by the community.

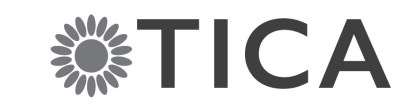

THE INTERNATIONAL COMPOSITAE ALLIANCE 


\section{CAPITULUM \\ THE INTERNATIONAL COMPOSITAE ALLIANCE NEWSLETTER}

\section{CAPITULUM}

CAPITULUM is the Newsletter of The International Compositae Alliance and is meant to be a venue for all things Compositae and welcomes all kinds of diversity in both its contributions and contributors. ISSN 2789-2786.

\section{EDITORIAL BOARD}

Mauricio Bonifacino

Universidad de la República, Montevideo, URUGUAY mbonifa@gmail.com

Ilse Breitwieser

Allan Herbarium - Landcare Research, NEW ZEALAND

breitwieseri@landcareresearch.co.nz

\section{Benoit Loeuille}

Royal Botanic Gardens, Kew, UK

b.loeuille@kew.org

Jennifer R. Mandel

University of Memphis, Tennessee, USA

jmandel@memphis.edu

\section{Abigail Moore}

University of Oklahoma, USA

abigail.j.moore@ou.edu

Erika Rae Moore

University of Memphis, Tennessee, USA

ermoore3@memphis.edu

Luis Palazzesi

Museo Argentino de Ciencias Naturales, ARGENTINA

Ipalazzesi@gmail.com

Lizzie Roeble

Naturalis Biodiversity Center, THE NETHERLANDS

lizzie.roeble@naturalis.nl

Gisela Sancho

Museo de la Plata, ARGENTINA

sancho@fcnym.unlp.edu.ar

\section{Alexander Schmidt-Lebuhn}

CSIRO, Centre for Australian National Biodiversity Research, AUSTRALIA Alexander.S-L@csiro.au

\section{Ed Schilling}

University of Tennessee, USA

eschilling@utk.edu

Alfonso Susanna

Botanic Institut of Barcelona, SPAIN

asusanna@ibb.csic.es

\section{SUBMISSIONS}

Manuscripts or photos intended for publication in CAPITULUM

are to be submitted at www.compositae.org 


\title{
A NOTE FROM THE EDITORIAL BOARD
}

\author{
on the new series of the TICA Newsletter
}

Thank you for joining us in this latest-actually just our second-issue of the reboot of the Compositae Newsletter, CAPITULUM. We made it! Issue I was a beautiful compilation of articles and images that we shared via email to The International Compositae Alliance (TICA) list, Twitter, colleagues, friends, and beyond.

In this second round, we've made some changes, notably we welcome six new members to the team of Associate Editors: Ilse Breitweiser (New Zealand), Luis Palazzesi (Argentina),

Gisela Sancho (Argentina), Ed Schilling (USA), Alexander Schmidt-Lebuhn (Australia), Alfonso Susanna (Spain).

CAPITULUM now has an ISSN: 2789-2786, and we have made some changes to the way we handle manuscripts with an eye toward setting up an online manuscript submission portal in 2022 (let's see!). In particular, each manuscript in Issue 2 was assigned a Handling/Associate Editor and has been peer reviewed by at least two referees. We believe this will ensure highquality articles are published in CAPITULUM and encourage a diverse set of submissions and submitters from the community.

In this second issue, we bring to you three 'Head Topics' articles: Alexander Schmidt-Lebuhn shares with us a review of taxonomy and phylogenetics of native Australian Asteraceae in "Daisies Down Under". Next, Ilse Breitwieser and J.M. Ward take us on a journey through the New Zealand indigenous Gnaphalieae, and finally Jennifer Ackerfield describes two new species of alpine thistles from the southern Rocky Mountains-one of which she names in memory of our late friend and colleague Vicki Funk. This issue hosts two articles in 'Brevia' one from Cristina Trujillo, María Victoria Valtierra, and Eduardo Marchesi describing a new record of Dasyphyllum (Barnadesieae) from Uruguay and another from Robert McKenzie, Kenneth

Oberlander, and Nigel Barker on the Arctotis annual clade in a semi-arid region of southern Africa. In 'Handlens', from Robb Eastman-Densem and Peter Pelser we learn about the complexity of New Zealand's Brachyglottis rotundifolia species complex (Senecioneae). Curious about the plants of the past? Abigail Moore brings us an exploration of the American West by exploring an herbarium sheet of Grindelia ciliata with two specimens, one collected by Thomas Nuttall and the other collected by Samuel Woodhouse about 30 years apart, yet mounted on the same sheet. In this issue's 'Pipet and the Press' Teng Zhang and Paula Elomaa describe methods and approaches for understanding capitulum development using Gerbera hybrida inflorescence meristem as an experimental system. Finally, view the stunning images from four contributors to 'Style':

Behnaz Balmaki, Phil Garnock-Jones, Oriane Hidalgo, and Jaume Pellicer.

Once again, we hope you enjoy reading our second issue of CAPITULUM.

Please share the newsletter broadly with friends and colleagues and consider sharing broadly.
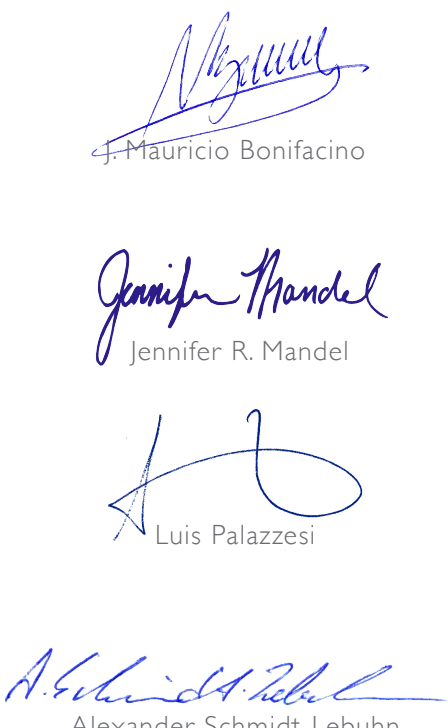

Alexander Schmidt-Lebuhn

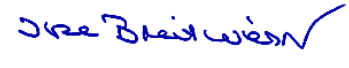

Ilse Breitwieser

Aliguil M. Merte

Szabeth Rople

Lizzie Roeble

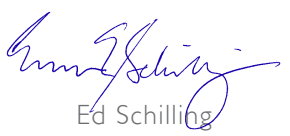

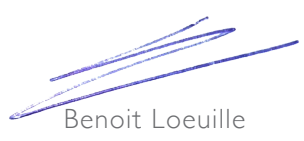

Erika Moore

Erika R. Moore

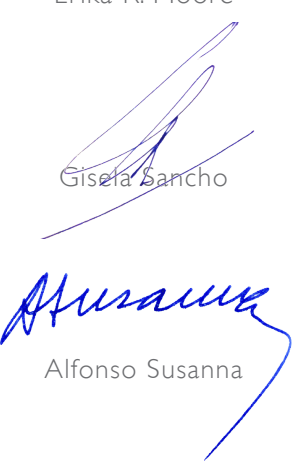

CAPITULUM | VOLUME | (2) | JANUARY 2022 | iii 


\section{CAPITULUM \\ THE INTERNATIONAL COMPOSITAE ALLIANCE NEWSLETTER}

VOLUME I (2) - JANUARY 2022

DOI: http://dx.doi.org/10.53875/capitulum.01.2

VERSION OF RECORD FIRST PUBLISHED ONLINE ON 29 JANUARY 2022

\section{CONTENTS}

\section{HEAD TOPICS}

Hiding in plain sight: Two new species of alpine thistles, Cirsium culebraensis and C. funkiae (Cardueae) from the southern Rocky Mountains (United States) | I

Jennifer R. Ackerfield

Diversity in New Zealand Gnaphalieae | 16

Ilse Breitwieser \& Josephine M.Ward

Daisies Down Under: Review of the state of taxonomy and phylogenetics of native Australian Asteraceae | 33 Alexander Schmidt-Lebuhn

\section{THE PIPET \& THE PRESS}

Understanding capitulum development: Gerbera hybrida inflorescence meristem as an experimental system | 53 Teng Zhang \& Paula Elomaa

\section{BREVIA}

Monarchs in the veld:The Arctotis Annual Clade provides insight into recent floristic diversification in a semi-arid region of southern Africa | 60

Robert J. McKenzie, Kenneth C. Oberlander \& Nigel P. Barker

New record of Dasyphyllum (Barnadesieae) from Uruguay | 74

Cristina Trujillo, Maria V.Valtierra \& Eduardo Marchesi

\section{THE HANDLENS}

It's complicated:A brief overview of the taxonomy of the New Zealand Brachyglottis rotundifolia species complex (Senecioneae) | 81 Robb Eastman-Densem \& Pieter Pelser

\section{THE CABINET}

Grindelia ciliata (Astereae), Thomas Nuttall, and the exploration of the American West | 89

Abigail J. Moore

STYLE | 98

TICA TALKS | IOI

GUIDELINES FOR AUTHORS | I 04

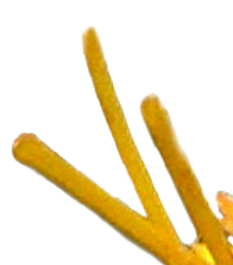

